\title{
Numerical Analysis of the Impact of the Cooling Cycle Length in Vegetable Cold Stores on the Heat Exchange with Soil
}

\author{
Paweł Sokołowski ${ }^{1 *}$, Grzegorz Nawalany ${ }^{1}$ \\ 1 University of Agriculture in Krakow, Faculty of Environmental Engineering, Department of Rural Building, \\ Al. Mickiewicza 24/28, 30-059 Kraków, Poland \\ * Corresponding author's e-mail: pawel.sokolowski@urk.edu.pl
}

\begin{abstract}
The paper includes an analysis of the impact of the cooling cycle length in vegetable cold stores on the heat exchange with soil. The scope involves the analysis of indoor and outdoor air temperature as well as soil temperature under the cold store and in its vicinity, specification and adaptation of the cold store-soil heat exchange model, model validation by comparison of the calculation results with experimental studies, choice of calculation variants, calculations for the used variants in non-stationary conditions, and a comparative analysis of the cold store-soil heat exchange for the used variants and of the soil temperature at selected solutions. The paper used the results of the field tests conducted in a vegetable cold store located in southern Poland. The building was used to store carrots from 1 October to 30 June. Four calculation variants were used for the in-depth study of the impact of selected factors on the heat exchange between the cold store and the soil. The calculations were performed based on the elementary balances method, using WUFI®plus software. The calculation model validation was based on the field measurements of indoor and outdoor air temperature as well as soil temperature in 5 measurement lines at the depth of $0.05,0.50,1.00$ and $1.50 \mathrm{~m}$. The obtained validation results showed a very good correlation between the measured and calculated data, in addition to an absence of significant differences. The calculation results for the 4 calculation variants showed significant differences in the heat exchange with soil.
\end{abstract}

Keywords: vegetable cold store, heat exchange, technological interruption, soil temperature

\section{INTRODUCTION}

The climatic and technological conditions in agricultural production necessitate storing fruit and vegetables for long periods of time. A significant development of the fruit and vegetable storage technology has been observed in recent years (Holsteijn and Kemna 2018, Richter and Bokelmann 2017, Tanner 2016). In order to reduce costs, growers are keener to form producer groups and cooperatives which have a significantly greater production potential than single farms (Nawalany et al. 2017, 2016). Currently, quality seems to be one of the most important criteria during the distribution of fruit and vegetables (Jha et al. 2019, Rouphael et al. 2018, Onwude et al. 2017). The quality of fruit and vegetables depends mainly on the storage conditions and methods (Ambaw et al. 2013, East et al. 2013, Liu et al. 2010).
Depending on the storage period and the type of product, it can be stored in traditional stores or cold stores. The appropriate storage method has a decisive impact on the shelf life of fruit and vegetables (Mazzeo et al. 2015, Jakubowski 2010, 2009, 2008, Łapczyńska-Kordon and Krzysztofik 2008). The basic threat for the product value deterioration is the water loss which causes a subsequent weight loss, and this in turn reduces the resistance to disease (Verboven et al. 2006, Adamicki $1997 \mathrm{a}, \mathrm{b})$. In addition to the quantity losses, the nutritional value is also reduced as a result of loss of vitamins (Ambaw et al. 2011, Ciećko 1993).

Depending on the type of stored crops, there are different types of stores and cold stores. Small farms usually have facilities used for most part of the year, with a technological interruption in summer (Chądzyński and Piróg 2013, Chądzyński 
2000). The technological interruption is used to prepare the store for the next storage season. One of the tasks performed during such interruption is disinfection of the storage rooms. It should be noted that the storage rooms are kept open throughout the technological interruption. This particularly applies to the soil under the floor, which accumulates heat during high temperatures, and such heat increases the amount of energy used for cooling at the beginning of the storage season. Thus, the following research problem can be formulated: what is the impact of the technological interruption length on the heat exchange with soil?

The subject of heat exchange with soil is well researched. It was studied by, inter alia, Radoń et al. (2014), Nawalany et al. (2017, 2014), Staniec (2009), Martin and Canas (2006), Janssen (2002) and Deru (2001). The problem of soil temperature has been important during the design of heating and cooling facilities in recent years, a fact that has been reflected in studies (Erol and Francois 2018, Zhao 2016, Kupiec et al. 2015, Fidorów and Szulgowska-Zgrzywa 2015, Flaga-Maryanczyk et al. 2014, Bertram 2014). In the case of a vegetable cold store, the soil is a heat receiver during the cooling cycle. During the technological interruption, the soil heats up.

The purpose of the research was to study the heat exchange between the vegetable cold store and the soil for the chosen length variants of the technological interruption.

The scope included an analysis of the indoor and outdoor air temperature as well as soil temperature under the cold store and in its vicinity, specification and adaptation of the cold store-soil heat exchange model, model validation by comparison of the calculation results with experimental studies, choice of calculation variants for various storage cycle lengths, choice of the calculation method and its adaptation (calculation tool adaptation), calculations for the used variants under non-stationary conditions, and a comparative analysis of the cold store-soil heat exchange for the used variants and of the soil temperature at selected variants.

\section{MATERIALS AND METHODS}

The field studies were conducted in a vegetable cold store in southern Poland. The store has two cold rooms and a sorting and packing area.
The total surface area of the facility is $232 \mathrm{~m}^{2}$, including $58 \mathrm{~m}^{2}$ of the sorting and packing area, $96 \mathrm{~m}^{2}$ of room A, and $78 \mathrm{~m}^{2}$ of room B (Fig. 1). The building has a steel frame structure on a $30-\mathrm{cm}$ wide concrete foundation located $1.0 \mathrm{~m}$ below the ground level. The fact that the foundation is not thermally insulated is important for the heat exchange with soil. The room floors are made of $10-\mathrm{cm}$ thick cement screed and feature a 4-cm thick EPS thermal insulation. An organoleptic soil examination showed that the cold store surrounding includes a $40-\mathrm{cm}$ thick humus layer, with a $1.5-\mathrm{m}$ thick layer of silty clay below it. The outside walls and ceiling of the rooms are made of sandwich panels, comprising steel sheets galvanized and painted on both sides and a $15-\mathrm{cm}$ thick EPS core. Polyurethane foam was used at the joints of panels to eliminate thermal bridges.

The storage cycle in the examined facility lasted from 15 October to 30 June, with a technological interruption from 1 July to 30 September. The optimum temperature was kept by a $20 \mathrm{~kW}$ refrigerating unit. The dimensions of cold rooms were adapted to multiple box pallets in which the carrots were kept. The distances between the box pallets and walls as well as between the box pallet rows were: $10 \mathrm{~cm}-30 \mathrm{~cm}$ and $5 \mathrm{~cm}-10 \mathrm{~cm}$, respectively.

The field studies were conducted between 1 May 2009 and 30 June 2011. The studies included continuous measurements of the indoor and outdoor air temperature, floor temperature and soil temperature, in 1-hour intervals. The temperature was measured by twenty two APATOR TOP 168 sensors based on a PT100 platinum resistor $\left(0.1{ }^{\circ} \mathrm{C}\right.$ measurement resolution, $0.1{ }^{\circ} \mathrm{C}$ measurement error). The sensors were connected to an HP $34970 \mathrm{~A}$ recorder. The measurement results were used to validate the calculation model.

Four calculation variants were used to study the impact of the technological interruption length on the indoor microclimate and the soil temperature under the cold store and in its vicinity: variant I - 3-month technological interruption, variant II - 2-month technological interruption, variant III - 1-month technological interruption, and variant IV - no technological interruption (all-year-long cooling).

The simulations were conducted in WUFI ${ }^{\circledR}$ plus software, which allows for calculating in a non-stationary approach using the method of elementary balances. 


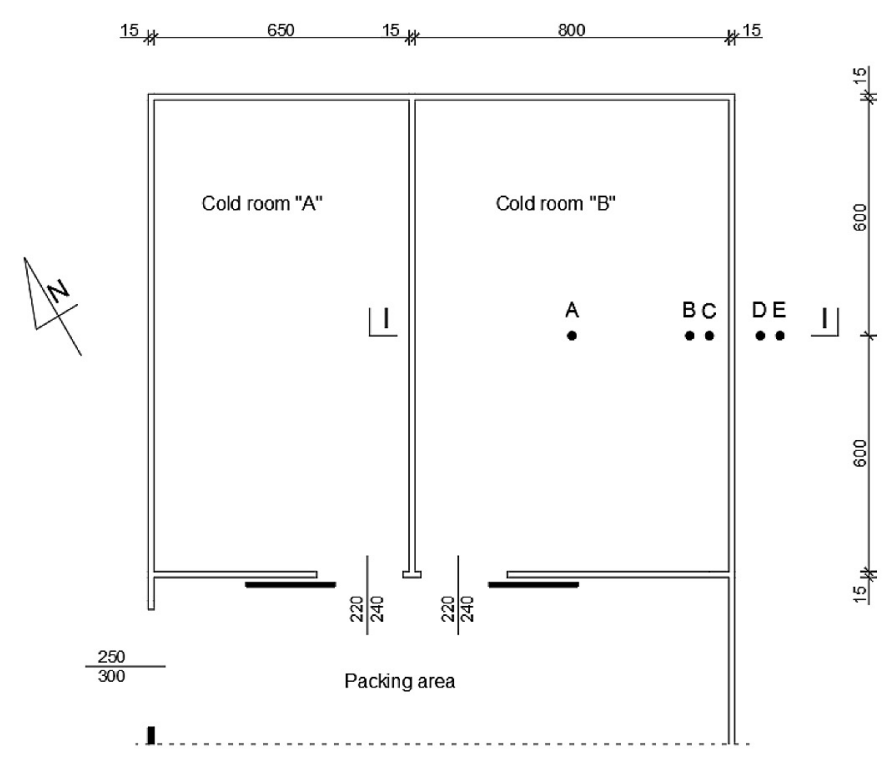

I-I

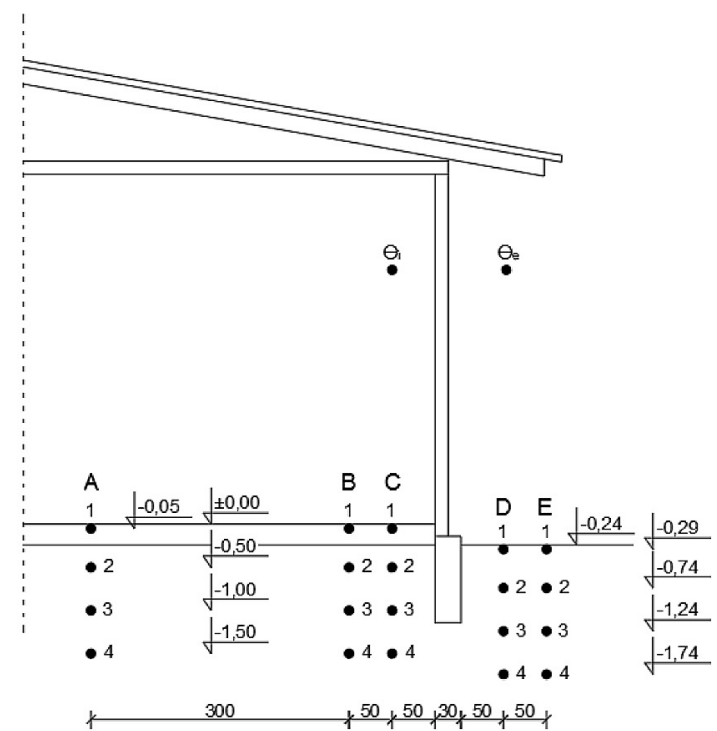

Fig. 1. Location of measurement points in the cold store: a) plan, b) section I-I: A, B, C, D, E - measuring lines, A1-A4, B1-B4, C1-C4, D1-D4, E1-E4 - soil temperature measurement points, $\Theta_{i}, \Theta_{e}-$ air temperature measurement points

Prior to the calculation analysis for the chosen variants, the software had to be validated based on the actual measuring data. The starting point for the model validation was to build a discrete geometrical model divided into balance-differential elements. The model included the measuring points corresponding to their actual location in the field-studied facility (Fig. 2) and featured the same technical parameters of construction materials and soil as in the real facility (Table 1).

In addition, the minimum indoor air temperature used in all variants was $\Theta_{i, \text { min }}=0^{\circ} \mathrm{C}$, maximum indoor air temperature $\Theta_{\mathrm{i}, \max }=4^{\circ} \mathrm{C}$, minimum indoor air relative humidity $\mathrm{Rh}_{\mathrm{i}, \min }=80 \%$, maximum indoor air relative humidity $\mathrm{Rh}_{\mathrm{i}, \max }=99 \%$. The natural air change was assumed at $0.3 \mathrm{~h}^{-1}$ and infiltration at $0.2 \mathrm{~h}^{-1}$.

\section{RESULTS AND DISCUSSION}

The validation calculations were based on the measured indoor and outdoor temperatures (Fig.3). During the studied period, the indoor air temperature was kept between $0.0^{\circ} \mathrm{C}$ and $4.0^{\circ} \mathrm{C}$. During the technological interruption in July, 


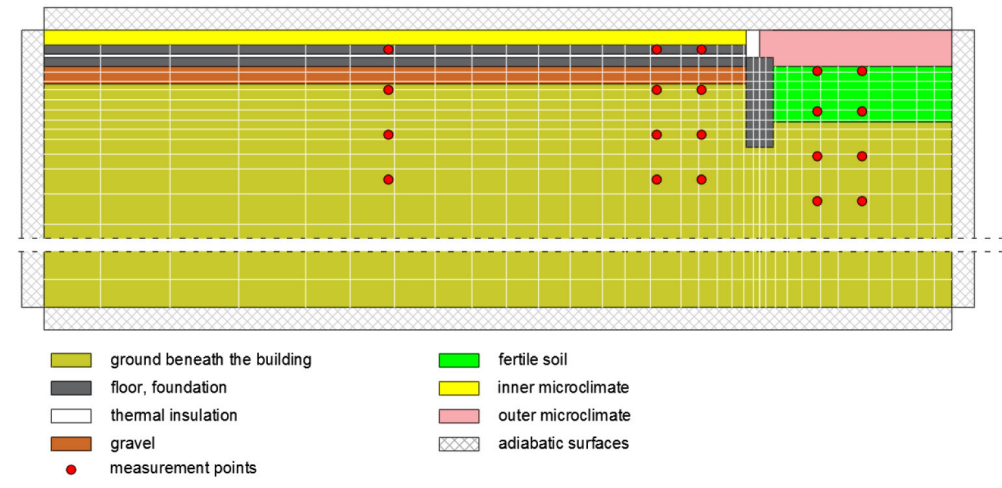

Fig. 2. Section of the modelled facility with the division network and layout of soil temperature calculation points (model from WUFI ${ }^{R}$ plus software)

August, September and the first half of October, the building was not cooled and remained open. The indoor air temperature in that period was in the $6.0-24.5^{\circ} \mathrm{C}$ range. The outdoor air temperature during the year fluctuated between $-15.4^{\circ} \mathrm{C}$ and $34.6^{\circ} \mathrm{C}$.

The floor temperature analysis in point $\mathrm{A} 1$ showed $4.2^{\circ} \mathrm{C}$ on the last day of the cooling period. On the first day of the next cooling cycle, the floor temperature was $11.6^{\circ} \mathrm{C}$ and decreased gradually. It was determined that in the analysed calculation variant, the time necessary to reduce the floor temperature to the value from the end of the storage period is 18 days.

At points $\mathrm{C} 1, \mathrm{~B} 1$ and $\mathrm{A} 1$ located in soil under the cold store, the annual soil temperature amplitude was in the $13.9^{\circ} \mathrm{C}-14.3^{\circ} \mathrm{C}$ range. $\mathrm{A}$ larger impact of soil on the stabilisation of thermal conditions is visible at the depth of $1.5 \mathrm{~m}$. At the depth of $0.50 \mathrm{~m}$, the annual temperature fluctuations were reduced almost twofold, compared to the depth of $0.05 \mathrm{~m}$. The impact of the cold store on the soil temperature decreases with depth. At the points located in the facility surrounding, the annual soil temperature amplitude varied from $14.5^{\circ} \mathrm{C}$ (point D2) to $15.1^{\circ} \mathrm{C}$ (point $\mathrm{E} 2$ ), and at points under the cold store, the amplitude was from $7.5^{\circ} \mathrm{C}(\mathrm{A} 2), 6.5^{\circ} \mathrm{C}(\mathrm{B} 2)$ and $6.6^{\circ} \mathrm{C}$ in $\mathrm{C} 2$ (Fig. 4).

The calculation model was validated based on the temperature measured inside and outside the cold store. In relation to the soil temperature, the measured temperature was a boundary condition of the third kind. The initial soil temperature was

Table 1. Physical parameters of the soil and construction materials used in the calculations

\begin{tabular}{|c|c|c|c|}
\hline & Specification & Unit & Value \\
\hline \multirow{3}{*}{ Clay } & density & $\mathrm{kg} \cdot \mathrm{m}^{-3}$ & 1600 \\
\hline & specific heat & $\mathrm{J} \cdot \mathrm{kg}^{-1} \cdot \mathrm{K}^{-1}$ & 1000 \\
\hline & thermal conductivity coefficient & $\mathrm{W} \cdot \mathrm{m}^{-1} \cdot \mathrm{K}^{-1}$ & 1.80 \\
\hline \multirow{3}{*}{ Humus } & density & $\mathrm{kg} \cdot \mathrm{m}^{-3}$ & 1800 \\
\hline & specific heat & $\mathrm{J} \cdot \mathrm{kg}^{-1} \cdot \mathrm{K}^{-1}$ & 1260 \\
\hline & thermal conductivity coefficient & $\mathrm{W} \cdot \mathrm{m}^{-1} \cdot \mathrm{K}^{-1}$ & 0.90 \\
\hline \multirow{3}{*}{ Eps } & density & $\mathrm{kg} \cdot \mathrm{m}^{-3}$ & 20 \\
\hline & specific heat & $\mathrm{J} \cdot \mathrm{kg}^{-1} \cdot \mathrm{K}^{-1}$ & 1500 \\
\hline & thermal conductivity coefficient & $\mathrm{W} \cdot \mathrm{m}^{-1} \cdot \mathrm{K}^{-1}$ & 0.04 \\
\hline \multirow{3}{*}{ Concrete } & density & $\mathrm{kg} \cdot \mathrm{m}^{-3}$ & 2300 \\
\hline & specific heat & $\mathrm{J} \cdot \mathrm{kg}^{-1} \cdot \mathrm{K}^{-1}$ & 1000 \\
\hline & thermal conductivity coefficient & $\mathrm{W} \cdot \mathrm{m}^{-1} \cdot \mathrm{K}^{-1}$ & 2.30 \\
\hline \multirow{3}{*}{ Gravel bedding } & density & $\mathrm{kg} \cdot \mathrm{m}^{-3}$ & 1800 \\
\hline & specific heat & $\mathrm{J} \cdot \mathrm{kg}^{-1} \cdot \mathrm{K}^{-1}$ & 840 \\
\hline & thermal conductivity coefficient & $\mathrm{W} \cdot \mathrm{m}^{-1} \cdot \mathrm{K}^{-1}$ & 0.90 \\
\hline \multirow{3}{*}{ Steel } & density & $\mathrm{kg} \cdot \mathrm{m}^{-3}$ & 7900 \\
\hline & specific heat & $\mathrm{J} \cdot \mathrm{kg}^{-1} \cdot \mathrm{K}^{-1}$ & 460 \\
\hline & thermal conductivity coefficient & $\mathrm{W} \cdot \mathrm{m}^{-1} \cdot \mathrm{K}^{-1}$ & 17.00 \\
\hline
\end{tabular}

Source: based on PN-EN ISO 6946:2008 


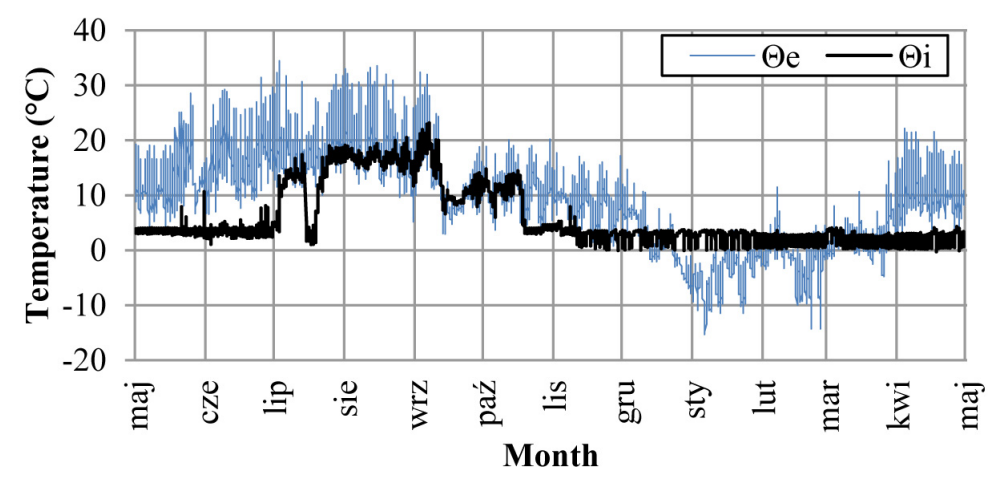

Fig. 3. Outdoor $\left(\Theta_{e}\right)$ and indoor $\left(\Theta_{i}\right)$ air temperatures from 1 May 2009 to 31 May 2010

assumed at $8.8^{\circ} \mathrm{C}$, which corresponds to the average annual outdoor air temperature for Krakow (TRY).

A correlation analysis was performed for the results obtained from all the measuring points, based on the Spearman's Rank Test (the data distribution was not normal). The data distribution normality was previously tested using the Shapiro-Wilk Test. The highest correlation coefficient $(0.95-0.99)$ was determined for measuring points E2, E3, E4, D2, D3, D4, C2, C3, C4, B2, $\mathrm{B} 3, \mathrm{~B} 4$, and $\mathrm{A} 2, \mathrm{~A} 3$ and $\mathrm{A} 4$. Consequently, the conformity of calculation and measurement data at the depth of $0.50 \mathrm{~m}, 1.00 \mathrm{~m}$ and $1.50 \mathrm{~m}$ can be considered full. In the case of the points E1 and $\mathrm{D} 1$, located $0.05 \mathrm{~m}$ below the ground level, and $\mathrm{A} 1, \mathrm{~B} 1$ and $\mathrm{C} 1$, located under the floor, the correlation coefficient was $0.85-0.88$, so the conformity of measurement and calculation data should be considered very high (Fig. 5).
It should be emphasized that in winter, the actual soil temperature at the depth of $0.10 \mathrm{~m}$ differed from the calculated values by $11.2^{\circ} \mathrm{C}$ in line $\mathrm{E}$ and $11.0^{\circ} \mathrm{C}$ in line $\mathrm{D}$. The reason was the impossibility to account for the snow cover. The differences occurred, however, only for a short time and were not significant for the entire period of the study. The statistical significance of differences was tested using the Kruskal-Wallis $(\mathrm{p}<0.05)$ test.

The analysis of the heat exchange intensity between the indoor air and the soil for variant 1 showed that the soil share in the total cold store energy balance was $16.6 \%$. The highest energy gains from the soil were found in October $(478.5 \mathrm{kWh})$. As a result of technological interruption in the summer, there was an intensive heat flow to the soil in July $(588.1 \mathrm{kWh})$. The simulation showed that the length of the cooling period during which the indoor air temperature a)

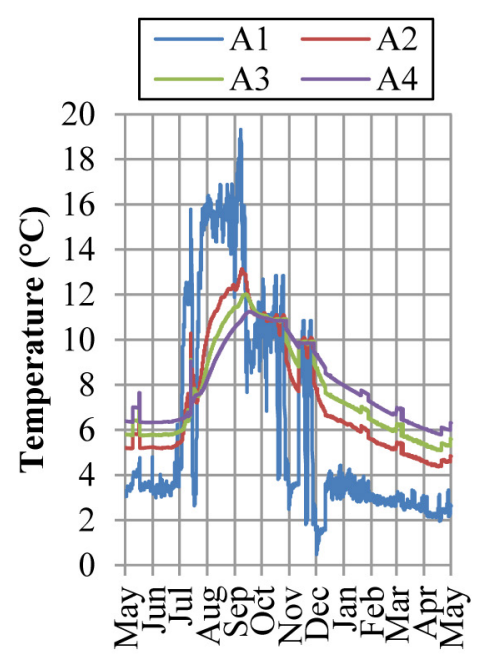

Month b)

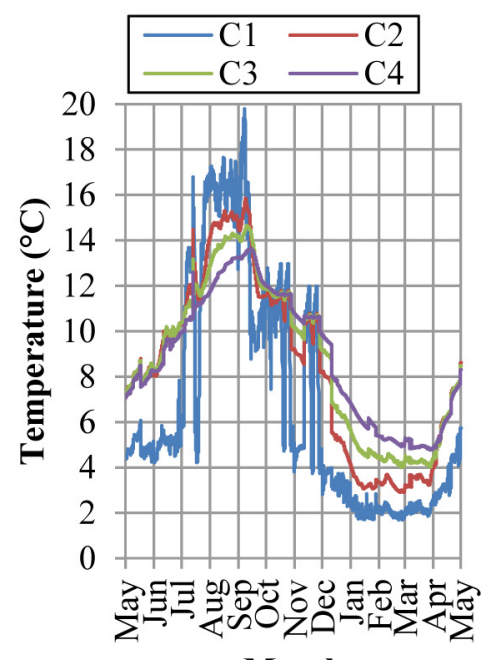

Month c)

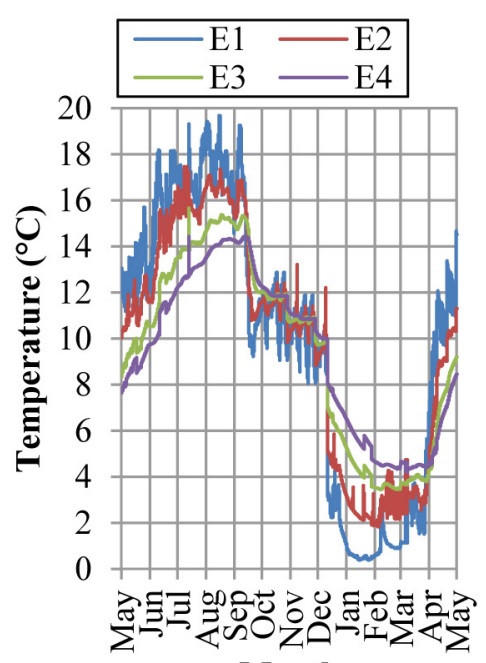

Month

Fig. 4. Measured soil temperatures in lines A, B and E:

a) temperature points $\mathrm{A} 1-\mathrm{A} 4, \mathrm{~b})$ points $\mathrm{C} 1-\mathrm{C} 4$, c) points $\mathrm{E} 1-\mathrm{E} 4$ 
a)

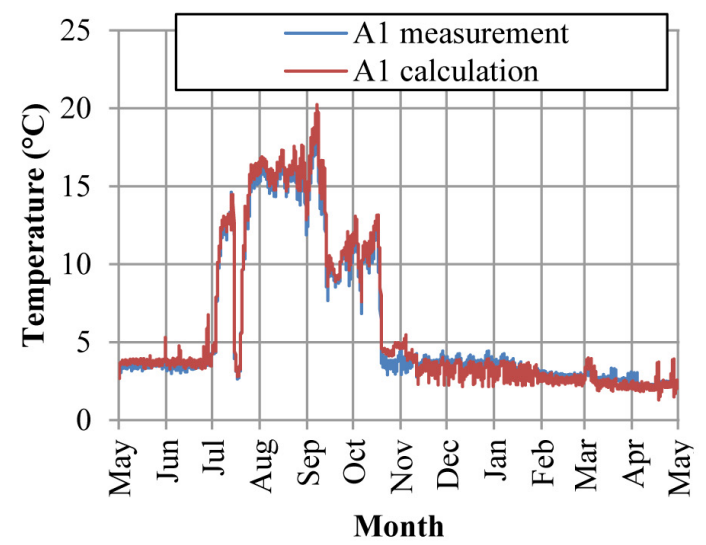

c)

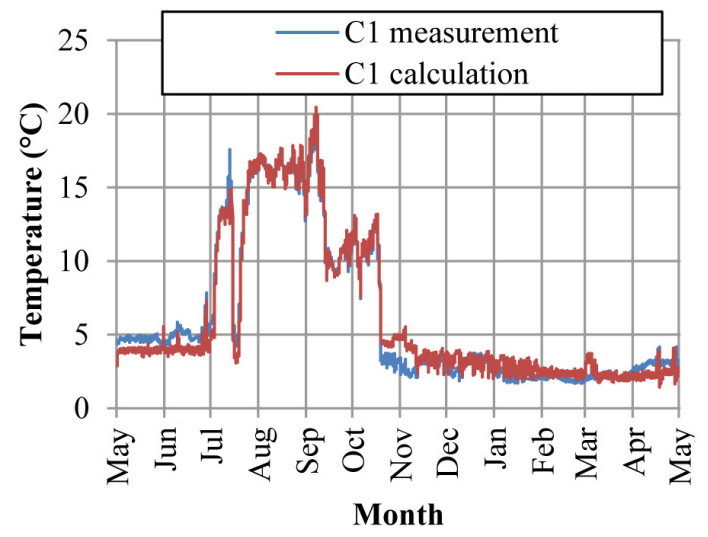

b)

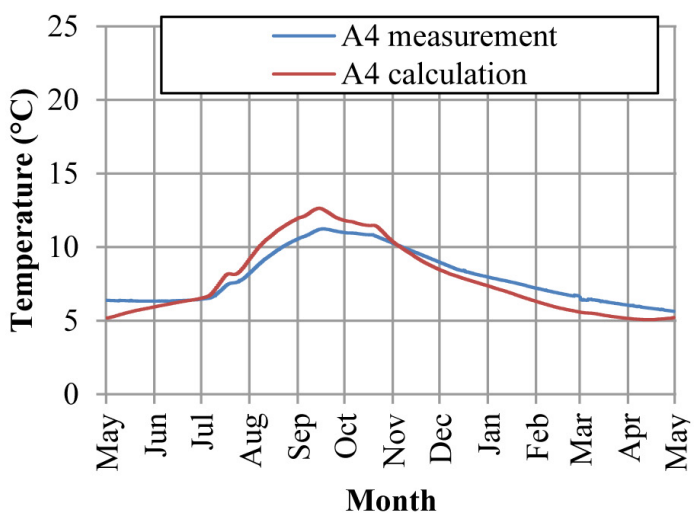

d)

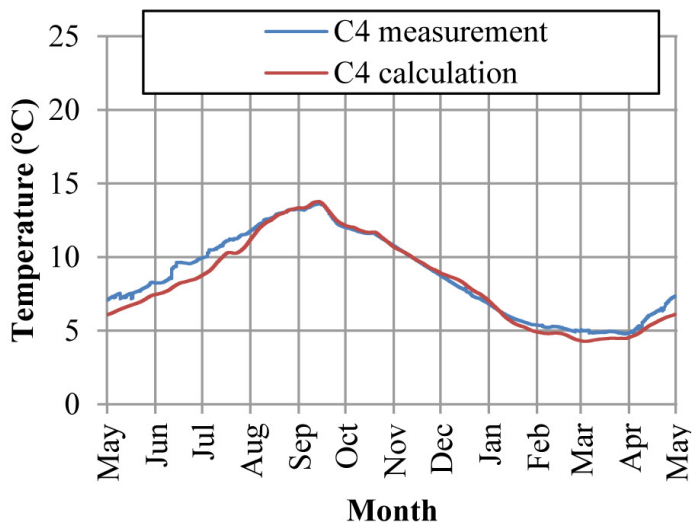

Fig. 5. Calculated and actual soil temperature: a) A1, b) A4, c) C1, d) C4

had to be reduced by a cooler was 155 days, and the period during which the air had to be heated was 27 days. The total energy demand for cooling in variant I was $5141.4 \mathrm{kWh}$, and for heating $527.2 \mathrm{kWh}$ (Fig. 6a).

Variant II included a 2-month technological interruption. The maximum heat gains from soil in this case were $251.6 \mathrm{kWh}$ and occurred in winter. The heat losses to the soil were found during the technological interruption, totalling 783.6 kWh in July and August (Fig. 6b). The soil share in the building energy balance was $6.7 \%$. The simulation showed that $5842 \mathrm{kWh}$ of energy during 183 days of active cooling would be necessary to ensure optimum thermal conditions inside the cold store. The total energy gains from the soil were $1523.5 \mathrm{kWh}$, and the losses $-1088.5 \mathrm{kWh}$.

The analysis of the result for a 1-month technological interruption for variant III showed an intensive heat outflow from the cold store to soil in July ( $436.2 \mathrm{kWh})$. The soil share in the annual cold store energy balance was $10.3 \%$. The total heat load was $653.6 \mathrm{kWh}$, and the cooling energy demand was $7649 \mathrm{kWh}$ (Fig. 6c). The calculation results showed a negative balance of the heat flow to the soil in July and March. In the remaining months, the heat flow was from the soil to the cold store.

The absence of technological interruption significantly affected the annual heat exchange with the soil. The analysis results for variant IV showed that the soil share in the cold store energy balance was $13 \%$. The indoor air cooling was required for 242 days in this variant. The heating period was 30 days. The cooling energy demand of the cold store was $9307 \mathrm{kWh}$, and the heating energy demand was $662 \mathrm{kWh}$ (Fig. 6d). The energy gains from the soil were from $44.2 \mathrm{kWh}$ to 236.2 $\mathrm{kWh}$. The maximum heat gain from the soil took place in December, and the greatest heat losses to the soil occurred in February (63.6 kWh).

In the case of the absence of technological interruption, it was determined that the soil temperature under the floor at the depth on $0.50 \mathrm{~m}$ 
a)

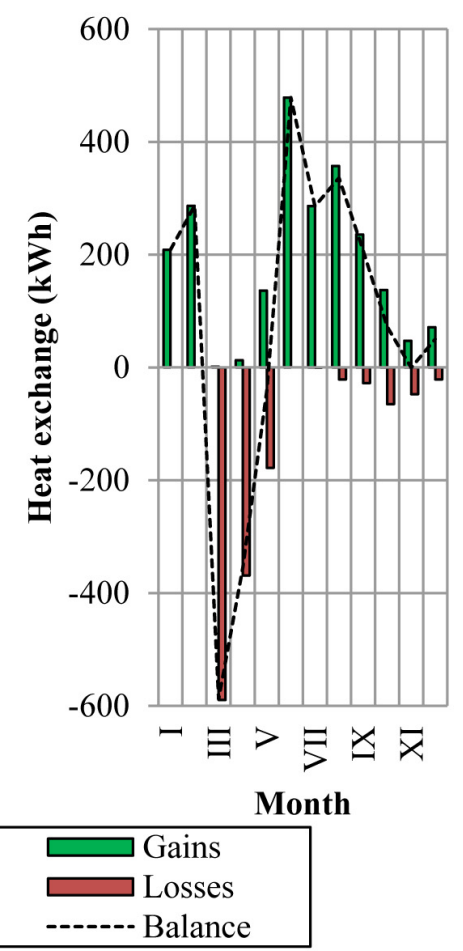

b)

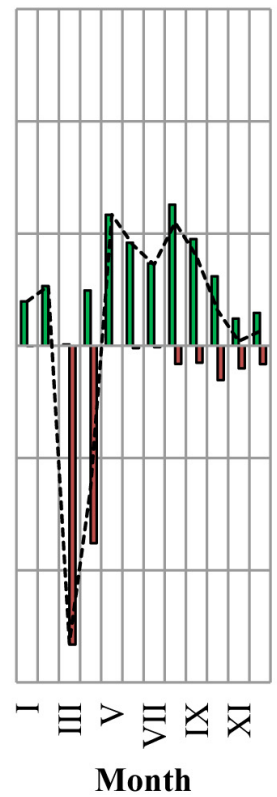

c)

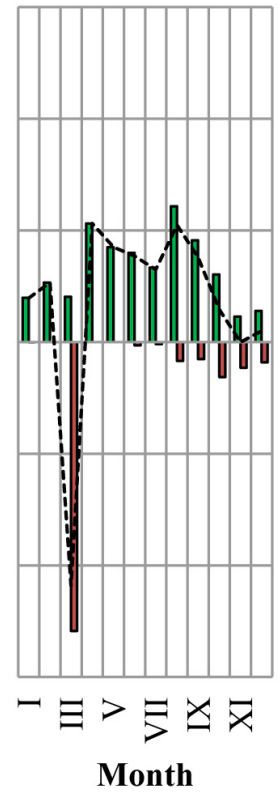

d)

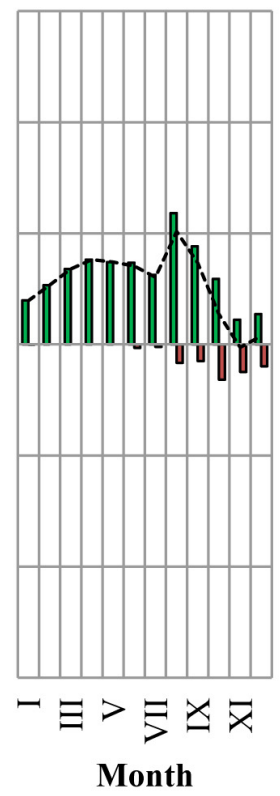

Fig. 6. Heat exchange between the cold store and soil: a) variant I, b) variant II, c) variant III, d) variant IV

on 1 October is $3.2{ }^{\circ} \mathrm{C}$ lower compared to the variants with technological interruptions. In the variants with technological interruptions, the soil temperature under the floor was similar to the variants with all-year-long cooling after 80 days from the start of the cooling season.

\section{CONCLUSIONS}

The heat exchange between the environment and the soil depends mainly on the soil physical parameters such as thermal conductivity coefficient, heat capacity and density. The size of the building envelopes in contact with the soil or surrounding air is also very important. In singlestorey buildings, where the ratio of usable area to the footprint is almost one, the soil share is higher due to a large area of envelopes in contact with the soil. A lower percent soil share in the total energy balance can be observed in multistorey buildings, with the same thermal insulation parameters.

The calculation model validation was based on the field measurements of the indoor and outdoor air temperature as well as soil temperature in 5 measurement lines at the depth of $0.05,0.50$,
1.00 and $1.50 \mathrm{~m}$. The obtained validation results showed a very positive correlation between the measured and calculated data and an absence of significant differences.

The technological interruption (July-September) reduces the annual cold store energy demand by $4300 \mathrm{kWh}$, but contributes to a $30 \mathrm{kWh}$ increase of energy demand in the first week of cooling. If the cold store is operated all year long (no technological interruption), the annual cooling energy demand increases more than twofold. The length of technological interruption has no significant effect on the heat exchange with soil. In terms of energy, only the fact of its presence or absence is important in the case of an all-yearlong cooling cycle.

\section{REFERENCES}

1. Adamicki F. 1997a. Przechowalnie czy chłodnie. Owoce Warzywa Kwiaty, 17-18.

2. Adamicki F. 1997b. Przechowywanie warzyw. Wydanie IV. Skierniewice.

3. Ambaw A., Delele M.A., Defraeye T., Ho Q.T., Opara L.U., Nicolai B.M., Verboven P. 2013. The use of CFD to characterize and design post-harvest 
storage facilities: Past, prezent and future. Computers and Electronics in Agriculture 93, 184-194.

4. Ambaw A., Delele M.A., Ho Q.T., Schenk A., Nicolai B.M., Verboven P. 2011. Modeling the diffusionadsorption kinetics of 1-methylocyclopropene (1$\mathrm{MCP}$ ) in Apple fruit and non-target materials in storage rooms. Journal of Food Engineering 102, 257-265.

5. Bertram E. 2014. Solar Assisted Heat Pump Systems with Ground Heat Exchanger - Simulation Studies. Energy Procedia. Vol. 48, 505-514.

6. Chądzyński A. 2000. Algorytm projektowania przechowalni i chłodni. Niepublikowana praca doktorska, Wydział Architektury, Pol. Wroc.

7. Chądzyński A., Piróg M. 2013. Obiekty do przechowywania owoców, warzyw lub ziemniaków. Budownictwo i Architektura 12 (3), 7-12.

8. Ciećko Z. 1993. Ocena jakości i przechowalnictwa produktów rolnych. P. Skrypt. Wyd. II UWM Olsztyn.

9. Deru M. 2001. Ground-Coupled Heat and Moisture Transfer from Buildings. Ph.D. Dissertation, Colorado State Univeristy, Fort Collins, CO.

10. East A.R., Smale N. J., Trujillo F.J. 2013. Potential for energy cost savings by utilising alternative temperature control strategies for controlled atmosphere stored apples. International Journal of Refrigeration, 36 (2013), 1109-1117.

11. Erol S., Francois B. 2018. Multilayer analitical model for vertical ground heat exchanger with groundwater flow. Geothermics. Vol. 71, 294-305.

12. Fidorów N., Szulgowska-Zgrzywa M. 2015. The influence of the ground caupled heat pump's labor on the ground temperature in the boreholes - study based on experimental data. Applied Thermal Engineering. Vol. 82, 237-245.

13. Flaga-Maranczyk A., Schnotale J., Radoń J., Wąs K. 2014. Experimental measurements and CFD simulation of a ground source heat exchanger operating at a cold climate for a passive house ventilation system. Energy and Buildings. Vol. 68, 562-570.

14. G. Nawalany, J. Radon, W. Bieda, P. Sokolowski. 2017. Influence of selected factors on heat exchange with the ground in a greenhouse. Transactions of the ASABE, Vol. 60 (2), 479-487.

15. Holsteijn F., Kemna R. 2018. Minimizing food waste by improving storage conditions in household refrigeration. Resources, Conservation and Recycling, Vol. 128, 25-31.

16. Jakbowski T. 2008. Wpływ promieniowania mikrofalowego na wybrane wskaźniki oceny przechowalniczej bulw ziemniaka. Acta Agrophysica, 2008, 12(2), 357-366

17. Jakubowski T. 2009. Wytrzymałość biologiczna skórki bulw ziemniaka napromieniowanych mikrofalami. Acta Agrophysica, 13(3), 685-693

18. Jakubowski T. 2010. Wpływ przechowywania na ubytki masy bulw ziemniaka napromieniowanych mikrofalami. Acta Agrophysica, 15(2), 293-303

19. Janssen H. 2002. The influence of soil moisture transfer on building heat loss via the ground. Ph.D. Dissertation, Departement Burgerlijke Bouwkunde. Katholieke Universiteit Leuven.

20. Jha P.K., Xanthakis E., Chevallier S., Jury V., LeBail A. 2019. Assessment of freeze damage in fruits and vegetables. Food Research International, Vol. 121, 479-496.

21. Kupiec K., Larwa B., Gwadera M. 2015. Heat transfer In horizontal ground heat exchangers. Applied Thermal Engineering, Vol. 75, 270-276.

22. Łapczyńska-Kordon B., Krzysztofik B. 2008. Wpływ sposobów i czasu przechowywania na wybrane właściwości fizyczne jabłek. Inżynieria Rolnicza 2(100), 179-185.

23. Liu Y., Langer V., Hogh-Jensen H., Egelyng H. 2010. Life Cycle Assessment of fossil energy use and greenhouse gas emissions in Chinese pear production. Journal of Cleaner Production 18 (2010), 1423-1430.

24. Martin S., Canas I. 2006. A comparison between underground wine Cellary and aboveground storage for the aging of Spanish wines. Transactions of ASABE 49 (5), 1471-1478.

25. Mazzeo T., Paciulli M., Chiavaro E., Visconti A., Pellegrini N. 2015. Impact of the industrial freezing process on selected vegetables - Part II. Colour and bioactive compounds. Food Research International, Vol. 75, September 2015, 89-97.

26. Nawalany G., Bieda W., Radoń J., Herbut P. 2014. Experimental study on development of thermal conditions in ground beneath a greenhouses. Energy and Buildings, Volume 69, February 2014, 103-111.

27. Nawalany G., Sokołowski P. 2016. Analysis of hygrothermal conditions of external partitions in an underground fruit store. Journal of Ecological Engineering, Vol. 17(4), 75-82.

28. Nawalany G., Sokołowski P., Herbut P., Angrecka S. 2017. Development of selected parameters of microclimate in a stand alone cellar plunged into soil. Journal of Ecological Engineering, Vol. 18(3), 156-161.

29. Onwude D.I., Hashim N., Janius R., Khalina A., Oladejo A.O. 2017. Non-thermal hybrid drying of fruits and vegetables: A review of current technologies. Innovative Food\&Science Engeneering Technologies, Vol. 43, 223-238.

30. Radoń J., Bieda W., Lendelova J., Pogran S. 2014. Computational model of heat exchange between 
dairy cow and bedding. Computers and Electronics in Agriculture, Volume 107, September, 29-37.

31. Richter B., Bokelmann W. 2017. Explorative study about the analysis of storing, purchasing and casting food by Rusing household diaries. Resources, Conservation and Recycling, Vol. 125, 181-187.

32. Rouphael Y., Kyriacou C.M., Petropoulos S.A. 2018. Improving vegetable quality in controlled environments. Scientia Horticulturae, Vol. 234, 275-289.
33. Staniec M. 2009. Analiza wpływu częsciowego zagłębienia budynku $\mathrm{w}$ gruncie na jego bilans energetyczny. Rozprawa doktorska, Politechnika Wrocławska.

34. Tanner D. 2016. Food Quality, Storage and Transport. Reference Module in Foof Science, 2016.

35. Zhao B. 2016. Study on heat transfer of ground heat exchanger based on wedgelet finite element method. International Communications in Heat and Mass Transfer. Vol. 74, 63-68. 